\title{
KONSEP DASAR PROSES KEPERAWATAN DALAM \\ MELAKUKAN ASUHAN KEPERAWATAN
}

\author{
Rahel Juliana Benedikta Berutu
}

Email : beruturahel1507@gmail.com

\section{Latar Belakang}

Sebelum menyusun suatu asuhan keperawatan yang baik, kita harusmemahami langkah langkah dari proses keperawatan. Proses perawatanmerupakan suatu metode bagi perawat untuk Memberikan asuihan keperawatan kepada klien. Proses keperawatan merupakan metode ilmiah yang dipakai dalam memberikan asuhan keperawatan yang profesional. Perawat, dimana saja ia bertugas, menghadapi klien dengan segala macam kasus, dan melayani klien pada semua tingkat usia juga harus menggunakan proses keperawatan. Perawat diharapkan memahami tentang konsep proses keperawatan dan mampu menerapkan serta menyusunannya dalam sebuah dokumen status kesehatan klien.

Proses keperawatan adalah aktivitas yang mempunyai maksud yaitu praktik keperawatan yang dilakukan dengan cara yang sistematik. Selama melaksanakan proses keperawatan, perawat menggunakan dasar pengetahuan yang komprehensif untuk mengkaji status kesehatan klien, membuat penilaian yang bijaksana dan mendiagnosa, mengidentifikasi hasil akhir kesehatan klien dan merencanakan, menerapkan dan mengevaluasi tindakan keperawatan yang tepat guna mencapai hasil akhir tersebut.

Proses keperawatan adalah salah satu metoda efektif pemecahan masalah yang dilakukan perawat terhadap klien dengan pendekatan metodologi ilmiah. Proses keperawatan adalah Suatu pendekatan sistematis untuk mengenal masalah-masalah pasien danmencarikan alternatif pemecahan masalah dalam memenuhi kebutuhan-kebutuhanpasien.Merupakan proses pemecahan masalah yang dinamis dalam memperbaiki danmeningkatkan kesehatan pasien sampai ke tahap maksimum.Merupakan pendekatan ilmiah.Terdiri dari 4 tahap : pengkajian, perencanaan, pelaksanaan dan evaluasi. Atau, adapula yang menterjemahkannya ke dalam 5 tahap : pengkajian, perumusan diagnosiskeperawatan, perencanaan, pelaksanaan dan evaluasi.

Proses keperawatan adalah inti dari dan esensi dari keperawatan, yang merupakan pusat dari tindakan keperawatan, dapat digunakan pada setting pelayanan. Proses keperawatan adalah satu pendekatan pemecahan masalah yang mendukung kemampuan perawat untuk mengatur dan memberikan asuhan keperawatan, proses keperawatan mengandung elemen berpikir kritis yang memungkinkan perawat dapat melakukan tindakan berdasarkan penalaran.

Proses keperawatan digunakan untuk membantu perawat melakukanpraktik keperawatan secara sistematis dalam memecahkan masalah keperawatan.Dengan 
menggunakan metode ini, perawat dapat mendemonstrasikan tanggunggugat dan tanggung jawab pada klien, sehingga kualitas praktik keperawatan dapatditingkatkan.Proses keperawatan memberikan kerangka yang dibutuhkan dalam asuhankeperawatan kepada klien, keluarga dan komunitas, serta merupakan metode yangefisien dalam membuat keputusan klinik, serta pemecahan masalah baik aktualmaupun potensial dalam mempertahankan kesehatan.

Kemampuan perawat dalam menerapkan proses keperawatan dalam asuhannya sudah tidak dapat ditawar lagi apabila ia meyakini bahwa asuhannya adalah asuhan yang profesional. Penerapan proses keperawatan dalam asuhan keperawatan kepada klien merupakan tanggung jawab dan tanggung gugat perawat kepada klien. Pada akhirnya, penerapan proses keperawatan ini akan meningkatkan kualitas layanan keperawatan kepada klien.

Kata Kunci : Konsep, Proses Keperawatan, Asuhan Keperawatan.

\section{METODE}

Metode penulisan yang digunakan dalam penulisan laporan ini adalah literature review. Literature review yang dilakukan berupa telaah pustaka artikel penelitian. Artikel dipublikasikan secara elektronik dan diunduh melalui Google Scholar,science direct, scopus, ebook, dan dari beberapa buku keperawatan.. Kata Kunci yang digunakan yaitu Konsep, Proses Keperawatan, Asuhan Keperawatan. Kriteria inklusi artikel adalah diterbitkan dari tahun 2012 hingga 2020, dan fulltext. Prosedur pengumpulan data yang digunakan adalah menentukan keyword untuk pencarian literatur yang relevan dengan topik kajian dan melakukan penelusuran mengenai topik relevan.

\section{HASIL}

Jurnal Hubungan Supervisi dengan Pelaksanaan Asuhan Keperawatan di Ruang Inap Lantai 10 Rumah Sakit Umum Royal Prima Medan Tahun 2017. Elis Anggeria dan Maria (2018). Metode Penelitian ini menggunakan desriftif correlative. Hasil penelitian yaitu bahwa dalam menjalan proses keperawatan dibutuhkan beberapa teori yaiti teori sistem, teori kebutuan manusia, teori persepsi, teori informasi dan komunikasi, teori pengambilan keputusan dan penyelesaian masalah, sehingga apabila teori ini dipahamin dapat mempermudah jalannya asuhan keperawatan.

Jurnal Pengaruh Berpikir Kritis Terhadap Kemampuan Perawat Pelaksana Dalam melakukan Asuhan Keperawatan di Rumah Sakit. Kiki Deniati, Ria anugrahwati, Tini Suminarti (2018). Metode penelitian menggunakan suvey analitik dengan pendekatan cross sectional. Hasil dari penelitian ini adalah Perawat yang memiliki kemampuan berfikir kritis akan menunjukkan sikap keberanian intelektual, berfikir terbuka, fleksibel, berfikir analisa, sistematis, percaya diri, rasa ingin tahu, dewasa, kreatifitas, intuisi dan pemikiran mendalam. Hasil penelitian lain yaitu sesuai dengan teori Ignatavicius \& Workman (2006) yang mengungkapkan bahwa berfikir kritis merupakan kompetensi yang perlu dimiliki oleh perawat agar dapat memberikan asuhan keperawatan yang berkualitas karena berfikir kritis sangat berkaitan dengan pengambilan keputusan dan penilaian klinis yang tepat. 
Jurnal Hubungan Karakteristik Perawat, Motivasi, dan Supervisi, dengan Kualitas Dokumentasi Proses Keperawatan. Retyaningsih ida yani, Bambang Edi Warsito (2013). Metode Penelitian yatitu penelitian kuantitatif yang menggunakan deaain penelitian potong lintang. Hasil dari penelitian yaitu Dokumentasi asuhan keperawatan menggunakan pendekatan proses keperawatan yang terdiri dari pengkajian, perumusan diagnosa, perencanaan, pelaksanaan, dan evaluasi sebagai metode ilmiah penyelesaian masalah keperawatan pada pasien untuk meningkatkan outcome pasien.

Jurnal Gambaran Tingkat Pengetahuan Perawat dalam Penerapan Asuhan Keperawatan Diruangan Rawap Inap Interna RSUD DHATOE BHINANGKANG. Luthfiani D.L. Achmadi, Linnie Pondag, Abram Babakal. (2015). Metode penelitian yaitu bersifat deskriftif. Hasil penelitian Penerapan asuhan keperawatan oleh tenaga perawat diruangan rawat inap interna laki-laki dan perempuan RSUD Datoe Binangkang kotamobagu, tergolong kategori baik. Tingkat pengetahuan yang tergolong baik hal ini sejalan dengan penerapan asuhan keperawatan yang baik.

Jurnal APLIKASI STANDAR PROSES KEPERAWATAN: DIAGNOSIS, OUTCOME, DAN INTERVENSI PADA ASUHAN KEPERAWATAN menyimpulkan pada penelitian ini menunjukkan bahwa sebagian besardokumen memiliki kualitas sedang pada dimensi diagnosis sebagai proses, sebagiandokumen memiliki kualitas sedang pada dimensi diagnosis sebagai produk, sebagian besardokumen memiliki kualitas sedang pada dimensi intervensi, dan sebagian besardokumen memiliki kualitas sedang pada dimensi luaran keperawatan.

\section{PEMBAHASAN}

Proses keperawatan adalah sarana atau alat yang digunakan oleh seorang perawat dalam bekerja dan tata cara pelaksanaanya tidak boleh dipisahpisah antara tahap pertama, kedua, ketiga dan seterusnya. Tahap pertama pengkajian, tahap kedua menegakkan diagnosa keperawatan, tahap ketiga menyusun rencana keperawatan yang mengarah kepada penanganan diagnosa keperawatan, tahap keempat diimplementasikan dan tahap kelima atau tahap terakhir adalah evaluasi. Orientasi dari pelayanan asuhan keperawatan adalah pada pencapaian tujuan asuhan keperawatan. Asuhan keperawatan yang telah ditetapkan dalam perencanaan keperawatan telah tercapai (Budiono, 2016).

Proses keperawatan adalah salah satu metoda efektif pemecahan masalah yang dilakukan perawat terhadap klien dengan pendekatan metodologi ilmiah. Proses keperawatan adalah Suatu pendekatan sistematis untuk mengenal masalah-masalah pasien danmencarikan alternatif pemecahan masalah dalam memenuhi kebutuhan-kebutuhanpasien.Merupakan proses pemecahan masalah yang dinamis dalam memperbaiki danmeningkatkan kesehatan pasien sampai ke tahap maksimum.Merupakan pendekatan ilmiah.Terdiri dari 4 tahap : pengkajian, perencanaan, pelaksanaan dan evaluasi. Atau, adapula yang menterjemahkannya ke dalam 5 tahap : pengkajian, perumusan diagnosiskeperawatan, perencanaan, pelaksanaan dan evaluasi.

Proses keperawatan adalah inti dari dan esensi dari keperawatan, yang merupakan pusat dari tindakan keperawatan, dapat digunakan pada setting pelayanan. Proses 
keperawatan adalah satu pendekatan pemecahan masalah yang mendukung kemampuan perawat untuk mengatur dan memberikan asuhan keperawatan, proses keperawatan mengandung elemen berpikir kritis yang memungkinkan perawat dapat melakukan tindakan berdasarkan penalaran.

Tujuan penerapan proses keperawatan bagi klien :

1. Mempertahankan kesehatan klien.

2. Mencegah sakit yang lebih parah/ penyebaran penyakit/ komplikasi akibat penyakit.

3. Membantu pemulihan kondisi klien setelah sakit.

4. Mengembalikan fungsi maksimal tubuh.

5. Membantu klien termial untuk meninggal dengan tenang.

Tujuan penerapan proses keperawatan dalam praktik keperawatan :

1. Mempraktikan metode pemecahan masalah dalam praktik keperawatan.

2. Meggunakn standar praktik keperawatan.

3. Memperoleh metode yang baku, rasional, dan sistematis.

4. Memperoleh hasil asuhan keperawatan dengan efektivitas yang tinggi.

Manfaat proses keperawatan bagi perawat :

1. Akan mempunyai rasa percaya diri, karena semua perencanaan disusun dengan baik berdasarkan kepada diagnosa keperawatan yang ditunjang oleh data-data yang tepat dan akurat.

2. Kepuasan kerja, karena memberikan peningkatan kualitas asuhan keperawatan sehingga mempercepat proses kesembuhan pasien.

3. Pengembangan profesionalisme keperawatan pada umumnya.

Manfaat proses keperawatan bagi klien :

1. Klien akan ikut berpartisipasi dalam menentukan perencanaan keperawatan dan akan meningkatkan kerjasama klien dalam pelaksanaan tindakan keperawatan.

2. Proses keperawatan menjamin klien akan mendapatkan asuhan keperawatan yang berkesinambungan.

3. Mencegah terjadinya duplikasi tindakan dan kekurangan tindakan.

4. Klien akan mendapatkan kualitas pelayanan asuhan keperawatan yang prima.

Manfaat proses keperawatan bagi rumah sakit atau puskesmas :

1. Kepuasan klien

2. Dengan sendirinya klien akan menceritakan kepuasannya kepada orang lain sehingga orang lain berkeinginan untuk mendapatkan kepuasan tersebut.

3. Meningkatkan jumlah klien. 
Sifat proses keperawatan :

1. Terbuka dan fleksibel Proses keperawatan menganut sistem terbuka. Jika sewaktu-waktu terjadi perubahan respon klien maka akan memberikan perubahan terhadap diagnosa, rencana dan tindakan yang akan diberikan. Fleksibel karena semua rencana yang telah disusun tidak serta merta harus dilaksanakan seluruhnya, tetapi harus melihat perubahan dan perkembangan kondisi.

2. Dilakukan melalui pendekatan individual Ada banayak hal yang bersifat individual dan merupakan privasi klien. Sehingga tidak kepda semua perawat diberikan kepercayaan oleh klien, atau tidak semua data (yang sehubungan dengan masalah keperawatan) akan disampaikan oleh klien. Pada situasi ini maka dibutuhkan suatu pendekatan yang individual kepada klien.

3. Penanganan masalah terencana Setelah masalah keperawatan ditemukan, maka akan disusun perencanaan yang berlandasarkan kepada ilmu keperawatan yang kokoh.

4. Mempunyai arah dan tujuan Perencanaan yang disusun mempunyai arah dan tujuan yang akan dicapai dalam batasan waktu tertentu.

5. Merupakan siklus yang saling berhubungan Setiap tahap saling berhubungan dan tidak dapat dipisah-pisah.

6. Terdapat validasi data dan pembuktian masalah Data yang dikumpulkan pada saat pengkajian betul-betul data yang diperoleh dari alat yang terukur dan diperoleh perawat yang terampil dan ahli.

Karakteristik Proses Keperawatan :

Tujuan : proses keperawatan mempunyai tujuan yang jelas melalui suatu tahapandalam meningatkan kualitas asuhan keperawatan.

Sistematik : menggunakan suatu pendekatan yang terorganisir untuk mencapaisuatu tujuanmeningkatkan kualitas asuhan keperawatan dan menghindari masalahyang bertentangan dengan tujuan pelayanan kesehatan / keperawatan.

Dinamik : proses keperawatan ditujukan dalam mengatasi masalah-masalahkesehatan lien yang dilaksanakan secara berkesinambungan. Proses keperawatanditujukan pada suatu perubahan respon klien yang diidentifikasi melalui hubunganantara perawat dan klien.

Interaktif : dasar hubungannya adalah hubungan timbal balik antar perawat, klien,keluarga dan tenaga kesehatan lainnya.

Fleksibel : dapat diadopsi pada praktik keperawatan dalam situasi apapun dan bisadigunakan secara berurutan.

Teoritis : setiap langah dalam proses keperawatan selalu didasarkan pada suatuilmu yang luas, khususnya ilmu dan model keperawatan yang berlandaskan padafilosofi keperawatan dan ditekankan pada aspek : humanisti, holistik dan care.

proses keperawatanmempunyai sembilan karakteristik antara lain, merupakan sistem yang terbuka dan fleksibel untuk memenuhi kebutuhan yang unikdari klien, keluarga, kelompok dan komunitas, bersifat siklik dan dinamis, karena semua tahap-tahap saling berhubungan danberkesinambungan, berpusat pada klien, merupakan pendekatan individual dan spesifik 
untuk memenuhikebutuhan klien, bersifat interpersonal dan kolaborasi, menggunakan perencanaan, mempunyai tujuan, memperbolehkan adanya kreativitas antara perawat dengan klien dalam memikirkan jalan keluar menyelesaikan masalah keperawatan, menekankan pada umpan balik, dengan melakukan pengkajian ulang dari masalahatau merevisi rencana keperawatan, dapat diterapkan secara luas. Proses keperawatan menggunakan kerangka kerjauntuk semua jenis pelayanan kesehatan, klien dan kelompok.

5 tahapan dalam proses keperawatan :

1. Tahap pengkajian : Mengumpulkan data, Pengelompokan/ mengatur data, Validasi data,Mendokumentasikan data

2. Tahap diagnosa kesehatan, resiko, kekuatan : Menganalisa data, Pengidentifikasi masalah, Merumuskan pernyataan, Diagnosa keperawatan

3. Tahap perencanaan : Memprioritaskan masalah, Merumuskan tujuan/ hasil, Memilih intervensi keperawatan, Menulis rencana keperawatan

4. Tahap implementasi : Mengkaji kembali pasien, Menentukan bantuan, Mengimplementasikan rencana, Tindakan keperawatan, Melalukan survei keperawatan Mendokumentasikan tindakan keperawatan

5. Tahap evaluasi hasil : Mengumpulkan data yang berhubungan dengan hasil, Membandingkan data, Menghubungkan tindakan keperawatan dengan tujuan/ hasil, Menarik kesimpulan tentang status masalah, Melanjutkan, memodifikasi atau mengakhiri rencana asuhan.

Langkah-langkah dalam proses keperawatan yaitu tahap Pengkajian Yang merupakan tahap awal dari proses keperawatan yang mencakup pengumpulan data (tahap ini adalah alat utama dalam pengkajian awal pasien dan merupakan proses konitinyu untuk memperoleh infornasi yang diperlukan untuk asuhan keperawatan penyusunan). validasi Data (tindakan double check atau verifikasi data untuk mengonfirmasi bahwa data-data yang telah terkumpul akurat dan factual). Pencatatan data (pada fase pengkajian yang lengkap perawat harus mencatat data yang akurat dan penting yang mencakup semua data status kesehatan pasien. Kemudian. Diagnosa Keperawatan merupakan langkah kedua dari proses keperawatan yang menggambarkan penilaian klinis tentang respon individu, keluarga, kelompok maupun masyarakat terhadap permasalahan kesehatan baik actual maupun potensial. Diagnosa keperawatan menurut NANDA adalah pertimbangan klinik tentang respon individu, keluarga, atau komunitas terhadap masalah-masalah kesehatan atau proses kehidupan aktual dan potensial. Perencanaan merupakan langkah ketiga dari proses keperawatan yaitu fase proses keperawatan yang sistematik, mencakup pembuatan kebutusan dan pemecahan masalah. Yang dimana tujuannya berpusat pada klien dan hasil yang diperkirakan ditetapkan dan intervensi keperawatan dipilih untuk mencapai tujuan tersebut. Intervensi adalah langkah ketiga dalam proses keperawatan yaitu tindakan yang dirancang untuk membantu klien dalam beralih dari tingkat kesehatan saat ini ketingkat yang diinginkan dalam hasil yang diharapkan (Gordon,1994). Terdapat 3 kategori dalam intervensi keerawatan yaitu mandiri (kegiatan yang dilakukan perawat berdasarkan pengetahuan dan keterampilan), tergantung(kegiatan yang dilakukan oleh perawat berdasarkan program dari dokter), kolaboratif (tindakan yang dilakukan perawat bersama-sama dengan anggota tim kesehatan lain seperti terapi fisik, pekerja sosial, ahli diet dan dokter). Implementasi yaitu tahap keempat dalam proses 
keperawatan, secara umum Implementasi terdiri dari mengerjakan, mendelegasikan dan pencatatan. Perawat melakukan tindakan sesuai dengan intruksi keperawatan yang dibuat, kemudian mengakhiri langkah implementasi dengan mencatat aktifitas yang dilakukan serta respon klien yang dihasilkan. Evaluasi adalah tahap akhir dari proses keperawatan. Perencanaan evaluasi memuat kriiteria keberhasilan proses dan keberhasilan tindakan keperawatan. Keberhasilan proses dapat dilihat dengan jalan membandingkan antara proses dengan pedoman/rencana proses tersebut. Sedangkan keberhasilan tindakan dapat dilihat dengan membandingkan antara tingkat kemandirian pasien dalam kehidupan sehari-hari dan tingkat kemajuan kesehatan pasien dengan tujuan yang telah di rumuskan sebelumnya. Evaluasi dapat dilakukan pada waktu kegiatan sedang dilakukan, intermitten dan terminal, evaluasi yang dilakukan pada saat kegiatan berjalan atau segera setelah implementasi meningkatkan kemampuan perawat dalam memodifikasi intervensi, evaluasi intermitten dilakukan pada interval khusus misalnya seminggu sekali, dilakukan untuk mengetahui kemajuan terhadap pencapaian tujuan dan meningkatkan kemampuan perawat untuk memperbaiki setiap kekurangan dan memodifikasi rencana keprawatan agar sesuai dengan kebutuhan. Evaluasi terminal menunjukkan keadaan pasien pada waktu pulang. Hal tersebut mencakup status pencapaian tujuan dan evaluasi terhadap kemampuan klien untuk perawatan diri sendiri sehubungan dengan perawatan lanjutan.ilmu kesehatan yaitu salah satunya Ilmu yang berkembang seiring kemajuan ilmu pengetahuan dan teknologi dan sesuai dengan perkembangan jaman. Keperawatan sebagai profesi merupakan salah satu pekerjaan dimana dalam menentukan tindakan didasari pada ilmu pengetahuan serta memiliki kertampilan yang jelas dalam keahliannya, selain itu sebagai profesi keperawatan mempunyai otonomi dalam kewenangan dan tanggung jawab dalam tindakan serta adanya kode etik dalam bekerjanya kemudian juga berorientasi pada pelayanan sehingga calam melaksanakan proses keperawatan melalui pemberian asuhan keperawatan kepada individu, kelompok atau masyarakat menjadi jauh lebih baik.

Asuhan keperawatan merupakan proses atau rangkaian kegiatan praktik keperawatan langsung pada klien di berbagai tatanan pelayanan kesehatan. Asuhan keperawatan dilaksanakan berdasarkan kaidah-kaidah keperawatan sebagai profesi yang berdasarkan ilmu dan kiat keperawatan, bersifat humanistik, dan berdasarkan kebutuhan objektif klien untuk mengatasi masalah yang dihadapi klien. Asuhan keperawatan merupakan inti pelayanan/praktik keperawatan

\section{PENUTUP}

\section{Kesimpulan}

Proses keperawatan digunakan untuk membantu perawat melakukanpraktik keperawatan secara sistematis dalam memecahkan masalah keperawatan.Dengan menggunakan metode ini, perawat dapat mendemonstrasikan tanggunggugat dan tanggung jawab pada klien, sehingga kualitas praktik keperawatan dapatditingkatkan.Proses keperawatan memberikan kerangka yang dibutuhkan dalam asuhankeperawatan kepada klien, keluarga dan komunitas, serta merupakan metode yangefisien dalam membuat keputusan klinik, serta pemecahan masalah baik aktualmaupun potensial dalam mempertahankan kesehata 


\section{Saran}

Sebelum menyusun suatu asuhan keperawatan yang baik, kita harusmemahami langkah langkah dari proses keperawatan. Proses perawatanmerupakan suatu metode bagi perawat untuk Memberikan asuihan keperawatankepada klien. Selain itu, Perawat harus memiliki kemampuan professional dalam melaksanakanpengkajian,karena pengkajian data merupakan dasar utama dari pelaksanaanproses keperawatan, pengkajian keperawatan harus dilakukan secara sistematis untuk memperoleh data akurat, dalam menentukan diagnose harus disesuaikan dengan kebutuhan klien, data yang diperoleh harus akurat dan bukan kesimpulan perawat, Perawat tidak boleh langsung membuat keputusan tentang kondisi klien.

\section{DAFTAR PUSTAKA}

Anggeria, E., Maria. (2018) . Hubungan Supervisi dengan Pelaksanaan Asuhan Keperawatan. 2018. Jurnal Jumantik, 3(2), 78-97.

Achmadi, Luthfiani, dkk. (2015). Gambaran tingkat pengetahuan perawat dalam penerapan standar asuhan keperawatan diruangan rawat inap interna RSUD Datoe Bhinangkang. EJournal Keperawatan (e-Kp) Vol (3) No (3).

Hidayah, N. (2014). Manajemen Model Asuhan Keperawatan Profesional (MAKP) Tim Dalam Peningkatan Kepuasan Pasien di Rumah Sakit Volume VII No. 2. Jurnal Kesehatan.

Koerniawan, D., Daeli, N., Srimiyati .(2020). APLIKASI STANDAR PROSES KEPERAWATAN: DIAGNOSIS, OUTCOME, DAN INTERVENSI PADA ASUHAN KEPERAWATAN. Jurnal Keperawatan SilampariVolume 3, Nomor 2, Juni 2020

Kusnadi, E. (2017). Analisis Kelengkapan Dokumentasi Keperawatan di Ruang Rawat InapNon IntensiveRumah Sakit X. Jurnal Bidang Ilmu Kesehatan Vol. 9, No. 1, Juni 2017

Lutfiani, D.L., Pondaag, L., \& Babakal, A.(2015). Gambaran Tingkat Pengetahuan Perawat dalam Penerapan Standar Asuhan Keperawatan di Ruangan Rawat Inap Interna RSUD Datoe Bhinangkang. E-jurnal keperawatan (EKP), 3 (3).

Simamora. R. H. (2008)The correlation of ward chief's giving direction and command and the performance of on-duty nurses at Jember dr. Subandi general hospital inpatient wards. jurnalAdministrasidanKebijakanKesehatan, (https://fkm.unair.ac.id/jurnal-administr)

Simamora, R. H. (2019). Development of Guidelines for Applying appropriate Patient Identification to Achieve Patient Safety Goal 
INC2019 12th International Nursing Conference. 2019.10455 - 455 (1 pages)UCI(KEPA) : I410-ECN-0101-2019-512-001224337

Sudarta, W. (2015). Managemen Keperawatan. Yogayakarta:GosyenPublishing

Sudono, B.,Setya, D., \& Atiningtyas, R. (2017). Gambaran Kemampuan Berpikir Kritis Perawat Primer dalam Pelaksnaan Asuhan Keperawatan di Rumah Sakit Islam Surakarta. Jurnal Ilmu Keperawatan Indonesia,10(1), 79-106.

Yanti, R.I., Warsito, B.E. (2013).Hubungan Karakteristik Perawat, Motivasi, dan Supervisi dengan Kualitas Dokumentasi Proses Asuhan Keperawatan. Jurnal Management Keperawatan, 1(2), 107-114.

Yeni, F. (2014). Pengaruh Pelatihan Proses Keperawatan terhadap DokumentasiAsuhan Keperawatan di Puskesmas Kabupaten Agam Propinsi Sumatera Barat. NERS JURNAL KEPERAWATAN Volume 10, No 1, Maret $2014:$ 21-27 